\title{
Synthesis, Characterization and Thermal Decomposition Kinetics of a Novel Benzofuran Ketoxime Derived Polymer
}

\author{
Zehra Bolat, ${ }^{1}$ Cumhur Kırılmıs ${ }^{1}$ and Adnan Kurt ${ }^{1} *$ \\ ${ }^{1}$ Department of Chemistry, Faculty of Arts and Science, Adiyaman University, 02040, Adiyaman/Turkey \\ * Corresponding author: E-mail: akurt@adiyaman.edu.tr \\ Tel: +90416 2233800; Fax: +904162231774
}

Received: 12-08-2014

\begin{abstract}
A novel benzofuran ketoxime derived polymer, poly(benzofuran-2-yl-methylketoxime-O-methacrylate) [poly(BMKMA], was firstly synthesized by free radical polymerization method. Its thermal degradation studies were performed by thermogravimetric analysis (TGA) in order to determine the actual reaction mechanisms of the decomposition process. The activation energy of the solid-state process was determined by using Flynn-Wall-Ozawa method, which resulted to be $235.9 \mathrm{~kJ} / \mathrm{mol}$. The activation energies of different mechanism models were determined by Coats-Redfern, Madhusudanan and Van Krevelen kinetic methods. Compared with the Ozawa method, the actual reaction mechanism obeyed deceleration type, phase boundary controlled reaction $\left(\mathrm{R}_{1}\right)$.
\end{abstract}

Keywrds: Synthesis, characterization, benzofuran, ketoxime, activation energy, thermogravimetric analysis.

\section{Introduction}

Heterocyclic polymers are useful materials due to their scientific and technologic importance such as biological, medicinal, chemical, physical and mechanical potentials. ${ }^{1-9}$ These properties shift depend on the heterocyclic group at the side chain of polymer. A class of very important heterocyclic compounds is benzofurans and their derivatives existing widely in natural products and unnatural compounds with physiological, pharmacological, toxic and optical potentials. Thus, much attention has been paid to the development of these compounds. ${ }^{10-12}$ Some different benzofuran derivative polymers have been successfully synthesized in recent years. ${ }^{13-16}$ In one of our previous studies, we synthesized and characterized a polymer containing benzofuran side group, poly(2-(5-bromo benzofuran-2-yl)-2-oxoethyl methacrylate), and we also investigated its thermal degradation kinetics. ${ }^{13}$ In another study, Yonezumi and coworkers ${ }^{14}$ studied the living cationic polymerization of benzofuran and some dihydrofurans using base-stabilized initiating systems with various Lewis acids. $\mathrm{Xu}$ and coworkers ${ }^{15}$ reported the electro-syntheses of poly(2,3benzofuran) films in boron trifluoride diethyl etherate containing poly(ethylene glycol) oligomers and some properties. Banihashemi and Atabaki ${ }^{16}$ reported the synthesis and characterization of thermally stable polybenzimidazoles derived benzofuran group. Pokladko and coworkers ${ }^{17}$ also studied on the synthesis and polymerization of novel methacrylates with benzofuranyl pendant groups for photovoltaic applications. Erol et al. ${ }^{18}$ reported the synthesis, characterization, monomer reactivity ratios and biological activity of new methacrylate copolymers based on the benzofuran ring.

Besides, thermogravimetric analysis (TGA) is widely used to investigate the thermal decomposition of polymeric materials. ${ }^{19-21}$ The TGA technique determines the amount and rate of change in the mass of a polymer sample as a function of temperature or time in a controlled atmosphere. The TGA measurements are used primarily to determine the thermal stabilities of polymers as well as their compositional properties. Its measurements provide valuable information that can be used for selection of polymeric materials to predict product performance, improve product quality and certain end-use applications. Thermal decomposition stabilities of methacrylate polymers change depending on cyclic groups on the polymer chains, which lead to increasing thermal 
stability. ${ }^{22}$ In the literature, it seems that there has not been enough work on the investigation of thermal degradation kinetics of methacrylate polymers with benzofuran and ketoxime derivatives so far. Therefore, the present study aims to synthesis, characterization and thermal decomposition process of poly(benzofuran-2-ylmethylketoxime-O-methacrylate), which is a new methacrylate polymer containing both benzofuran and ketoxime side groups.

\section{Theory}

The application of dynamic TGA methods holds great promise as a tool for unraveling the mechanisms of physical and chemical processes that occur during polymer degradation. The kinetics of polymer degradations is usually described by the basic kinetic equation:

$$
\frac{\mathrm{d} \alpha}{\mathrm{d} t}=k(T) f(\alpha)
$$

where $f(\alpha)$ and $\mathrm{k}(T)$ are functions of conversion and temperature, respectively. $f(\alpha)$ depends on the particular decomposition mechanism and $\mathrm{k}(T)$, the temperature dependence of the rate of weight loss, $t$ is time and $\alpha$ represents the fraction of conversion. The value of $\alpha$ is experimentally determined by TGA as a relative mass loss. In many cases, the temperature dependence of $\mathrm{k}(T)$ can be defined by the Arrhenius equation, whose substitution into Eq. 1 yields:

$$
\frac{\mathrm{d} \alpha}{\mathrm{d} t}=A \exp \left(-\frac{E}{\mathrm{R} T}\right) f(\alpha)
$$

where $E$ is the activation energy, $A$ is the preexponential factor, $T$ is the absolute temperature, and $\mathrm{R}$ is the universal gas constant. The last equation is integrated with the initial condition of $\alpha=0$ at $T=0$ to any condition of $\alpha=\alpha_{\mathrm{p}}$ at $T=T_{\mathrm{p}}$ to obtain the following expression:

$$
\mathrm{g}(\alpha)=\int_{0}^{\alpha_{\mathrm{p}}} \frac{\mathrm{d} \alpha}{f(\alpha)}=\frac{A}{\beta} \int_{0}^{\mathrm{T}_{\mathrm{p}}} \mathrm{e}^{-\frac{E}{\mathrm{R} T}} \mathrm{~d} T
$$

Different expressions of integral function of conversion for solid-state reaction mechanisms may be seen in literature ${ }^{13}$ In order to estimate the thermal degradation mechanism, these functions can be applied to thermogravimetry. ${ }^{23}$

\section{1. Flynn-Wall-Ozawa Method}

Flynn-Wall-Ozawa method ${ }^{24,25}$ is one of the integral methods that can determine the activation energy without a knowledge of reaction order and differential data of TGA. It is used to determine the activation energy for given values of conversion. Flynn-Wall-Ozawa method uses the following equation:

$$
\log \beta=\log \left[\frac{A E}{g(\alpha) \mathrm{R}}\right]-2.315-\frac{0.457 E}{\mathrm{R} T}
$$

where $\beta$ is the heating rate. The activation energy, $E$, is calculated from the slope of a plot of $\log \beta$ versus $(1000 / T)$, which is equal to $(-E / \mathrm{R})$.

\section{2. Coats-Redfern Method}

Coats-Redfern method ${ }^{26}$ is also an integral method, and it involves the thermal degradation mechanism. Using an asymptotic approximation for resolution of $E q$. 3, the following equation can be obtained:

$$
\ln \frac{g(\alpha)}{T^{2}}=\ln \frac{A \mathrm{R}}{\beta E}-\frac{E}{\mathrm{R} T}
$$

According to the different degradation processes, $\mathrm{E}$ and A can be determined from a plot of $\ln \left[g(\alpha) / T^{2}\right]$ versus 1000/T.

\section{3. Madhusudanan Method}

As well as the Coats-Redfern method, the most probable mechanism may also be determined providing that Eq. 3 is solved in different ways. Thus, the accuracy of calculation may be increased. One of these solutions is suggested by Madhusudanan et al. ${ }^{27}$ as represented with a kinetic Eq. 6:

$$
\begin{aligned}
& \ln \left[\frac{g(\alpha)}{T^{1.921503}}\right]=\left[\ln \frac{A E}{\beta \mathrm{R}}+3.772050-\right. \\
& -1.921503 \ln E]-1.000955716 \frac{E}{\mathrm{R} T}
\end{aligned}
$$

A plot of $\ln \left[g(\alpha) / T^{1.921503}\right]$ versus $1000 / T$ and fitting to a straight line would give a slope of $-1.000955716 E / R$.

\section{4. Van Krevelen Method}

Van Krevelen ${ }^{28}$ method was also used to verify the solid state thermodegradation mechanism of polymer. Eq. 7 to determine the activation energies and correlations by Van Krevelen method is as below:

$$
\log g(\alpha)=\log B+\left(\frac{E}{\mathrm{R} T_{r}}+1\right) \log T
$$

where $T_{\mathrm{r}}$ is a reference temperature. It was taken as the 
maximum temperature rate determined from derivative thermogravimetry in this work. The activation energies of every $g(\alpha)$ function were calculated from the slope of lines of $\log g(\alpha)$ versus $\log T$ plots.

\section{Experimental}

\section{1. Instrumental Techniques}

Infrared spectra were recorded on a Perkin Elmer Spectrum 100. ${ }^{1} \mathrm{H}$ and ${ }^{13} \mathrm{C}$-NMR spectra were recorded on a Bruker Avence II $400 \mathrm{MHz}$ NMR spectrometer at room temperature using $\mathrm{CDCl}_{3}$ as a solvent and TMS as an internal standard. Thermogravimetric analysis was performed using a Shimadzu TG-50 system. The thermal stability measurements were carried out from ambient temperature to $400{ }^{\circ} \mathrm{C}$ with different heating rates of $5{ }^{\circ} \mathrm{C} / \mathrm{min}, 10{ }^{\circ} \mathrm{C} / \mathrm{min}, 15{ }^{\circ} \mathrm{C} / \mathrm{min}$ and $20{ }^{\circ} \mathrm{C} / \mathrm{min}$. All the experiments were carried out in a nitrogen atmosphere. The optimum gas flow rate was $25 \mathrm{ml} / \mathrm{min}$.

\section{2. Materials}

All chemicals and solvents used in this study were analytical grade. Calicylaldehiyde, chloroacetone, hydroxylamine hydrochloride, pyridine, methacryloyl chloride, anhydrous magnesium sulfate and potassium carbonate, tetrahydrofuran, 1,4-dioxane, acetone were received from Merck.

\section{3. Synthesis of Benzofuran-2-yl- methylketone Compound (1)}

1-Chloroacetone $(9.253 \mathrm{gr}, 7.96 \mathrm{~mL}, 0.1 \mathrm{~mol})$ in acetone $(15 \mathrm{~mL})$ was successively added to a mixture of calicylaldehyde (12.82 gr, $10.96 \mathrm{~mL}, 0.105 \mathrm{~mol})$ and anhydrous $\mathrm{K}_{2} \mathrm{CO}_{3}(20.7 \mathrm{gr}, 0.15 \mathrm{~mol})$. The reaction mixture was stirred and refluxed for 70 minutes. Then, the reaction mixture was cooled to room temperature, precipitated in water, filtered and washed with water by several times, respectively. The compound (1) was crystallized from ethanol (yield: 62\%).

${ }^{1} \mathrm{H}-\mathrm{NMR}\left(\mathrm{CDCl}_{3}, \delta \mathrm{ppm}\right): 7.23-7.68$ (aromatic ring protons and furan $=\mathrm{CH}$ proton $), 2.67(3 \mathrm{H}$, methyl protons).

${ }^{13} \mathrm{C}-\mathrm{NMR}\left(\mathrm{CDCl}_{3}, \delta \mathrm{ppm}\right): 190.53$ (ketone carbonyl carbon), 157.64 (ipso carbon in aromatic ring next to furan oxygen), 154.64 (ipso carbon in furan ring), $130.22-114.40$ (aromatic ring carbons and $=\mathrm{CH}$ carbon in furan ring), 28.40 (methyl carbon).

FTIR $\left(\mathrm{cm}^{-1}\right.$, the most characteristic bands): 3130-3078 $\mathrm{cm}^{-1}$ (aromatic C-H stretching), 2980-2935 $\mathrm{cm}^{-1}$ (aliphatic $\mathrm{C}-\mathrm{H}$ stretching), $1669 \mathrm{~cm}^{-1}$ (sharp, ketone $\mathrm{C}=\mathrm{O}$ stretching $), 1605 \mathrm{~cm}^{-1}(\mathrm{C}=\mathrm{C}$ stretching in aromatic ring), $1076 \mathrm{~cm}^{-1}$ (C-O-C stretching).

\section{4. Synthesis of Benzofuran-2-yl-methylke- toxime Compound (2)}

To a $250 \mathrm{~mL}$ round-bottom flask, Benzofuran-2-ylmethylketone $(9.00 \mathrm{gr}, 0.056 \mathrm{~mol})$, hydroxylamine hydrochloride ( $4.69 \mathrm{gr}, 0.067 \mathrm{~mol}$ ) and $75 \mathrm{~mL}$ of pyridine were respectively added, and the solution was refluxed about 40 minutes. After this time, the mixture was cooled, precipitated in water, filtered, washed with excessive water, and dried, respectively (yield: 95\%).

${ }^{1} \mathrm{H}-\mathrm{NMR}\left(\mathrm{CDCl}_{3}, \delta \mathrm{ppm}\right)$ : 7.29-8.26 (aromatic ring protons and furan $=\mathrm{CH}$ proton), 3.38 (methyl protons).

${ }^{13} \mathrm{C}-\mathrm{NMR}\left(\mathrm{CDCl}_{3}, \delta \mathrm{ppm}\right): 171.18(\mathrm{C}=\mathrm{N}$ carbon), 155.72 (ipso carbon in aromatic ring next to furan oxygen), 151.32 (ipso carbon in furan ring), 127.30-114.05 (aromatic ring carbons and $=\mathrm{CH}$ carbon in furan ring), 13.40 (methyl carbon).

FTIR $\left(\mathrm{cm}^{-1}\right.$, the most characteristic bands): 3223 (O$\mathrm{H}$ stretching), 3129-3075 $\mathrm{cm}^{-1}$ (aromatic C-H stretching), 2980-2933 $\mathrm{cm}^{-1}$ (aliphatic C-H stretching), $1626(\mathrm{C}=\mathrm{N}$ stretching), $1603 \mathrm{~cm}^{-1}$ ( $\mathrm{C}=\mathrm{C}$ stretching in aromatic ring).

\section{5. Synthesis of Benzofuran-2-yl-methylke- toxime-O-methacrylate Monomer (3)}

The solution of methacryloyl chloride (4.942 gr, $4.58 \mathrm{~mL}, 0.0473 \mathrm{~mol}$ ) in THF was drop wised to the solution of benzofuran-2-yl-methylketoxime $(8.20 \mathrm{gr}, 0.0468$ $\mathrm{mol})$ in THF $(65 \mathrm{~mL})$ at $0-5{ }^{\circ} \mathrm{C}$. Then, the mixture was stirred at the room temperature for 3 hours. At the end of the reaction, THF was evaporated and the organic residue was dissolved in chloroform. Then, it was extracted with dilute $\mathrm{NaHCO}_{3}$ solution several times. The organic phases were collected and dried over anhydrous $\mathrm{MgSO}_{4}$. After the chloroform had evaporated, benzofuran-2-yl-methylketoxime-O-methacrylate monomer (BMKMA) was obtained at the yield of $80 \%$. The synthesis of monomer was shown in Scheme 1.

\section{6. Free Radical Polymerization of BMKMA Monomer}

Appropriate amounts of the BMKMA monomer $(1.5 \mathrm{~g}), 1,4$-dioxane $(4.5 \mathrm{~mL})$ and benzoyl peroxide $(0.003$ $\mathrm{g}, 0.2 \%$ of the monomer) were placed in a polymerization tube and purged with Ar for $10 \mathrm{~min}$. After the tube had been kept at $65^{\circ} \mathrm{C}$ for $25 \mathrm{~h}$, the contents were poured into a large amount of methanol. The polymer, poly(BMKMA), was purified by reprecipitation with methanol several times, and finally dried in a vacuum.

\section{Results and Discussion}

The molecular structure of benzofuran-2-ylmethylketoxime-O-methacrylate, BMKMA, was cha- 
<smiles>CC(=O)c1cc2ccccc2o1</smiles>

(1)<smiles>CC(=O)c1cc2ccccc2o1</smiles><smiles>[R10]C1CCCCC1/C(C)=N/O</smiles>

(2)<smiles>C=C(C)C(=O)Cl</smiles><smiles>C=C(C)C(=O)O/N=C(/C)c1cc2ccccc2o1</smiles>

(3)

Scheme 1. Synthesis of BMKMA monomer

racterized by FTIR, ${ }^{1} \mathrm{H}-\mathrm{NMR}$ and ${ }^{13} \mathrm{C}$-NMR techniques. Fig. 1a shows the FTIR spectrum of BMKMA monomer, in which the absorption peaks at $3130-3076 \mathrm{~cm}^{-1}$ are characteristic for aromatic $\mathrm{C}-\mathrm{H}$ stretching. The peaks at $2981-2930 \mathrm{~cm}^{-1}$ are due to $\mathrm{C}-\mathrm{H}$ stretching of aliphatic methylene and methyl groups. The strong absorbance at $1737 \mathrm{~cm}^{-1}$ is attributed to a vibration characteristic of methacrylic ester carbonyl. BMKMA monomer was especially characterized from the aliphatic and aromatic $\mathrm{C}=\mathrm{C}$ stretching bands observed at 1634 $\mathrm{cm}^{-1}$ and $1600 \mathrm{~cm}^{-1}$, respectively. The absorption at $1600 \mathrm{~cm}^{-1}$ is also attributed to $\mathrm{C}=\mathrm{N}$ stretching. As it can be seen in Fig. 1a, the presence of stretching of both carbonyl and $\mathrm{C}=\mathrm{C}$ bands proves the formation of $\mathrm{BMK}$ MA monomer.

Fig. 2a shows the ${ }^{1} \mathrm{H}-\mathrm{NMR}$ spectrum of BMKMA monomer. The multiplet resonance absorptions between $7.57 \mathrm{ppm}$ and $7.17 \mathrm{ppm}$ are characteristic for aromatic protons on the benzene group and furan $=\mathrm{CH}$ proton. The singlets at $6.13 \mathrm{ppm}$ and $5.53 \mathrm{ppm}$ are due to the protons in vinyl group. The resonances at $2.37 \mathrm{ppm}$ and $1.97 \mathrm{ppm}$ are attributed to methyl protons next to vinyl group and furan ring, respectively.
The ${ }^{13} \mathrm{C}-\mathrm{NMR}$ spectrum of BMKMA monomer which shown in Fig. 3 is also compatible with its structure, where the signal at 163.89 ppm corresponds to metha-

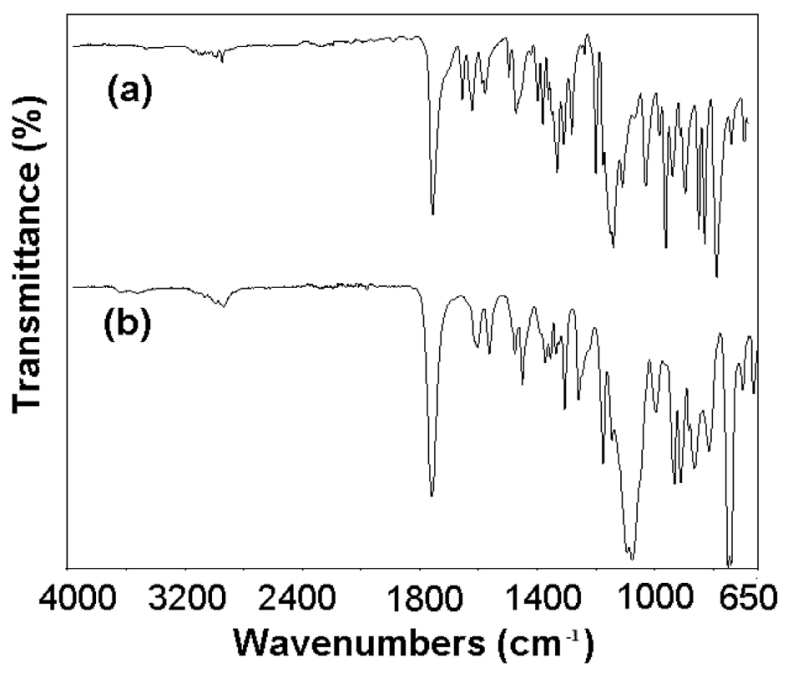

Fig. 1. FTIR spectra of a) BMKMA monomer, b) poly(BMKMA) homopolymer. 

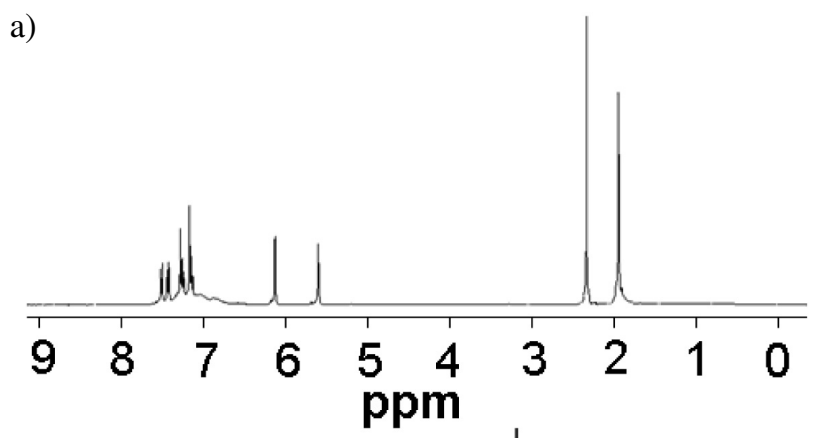

b)

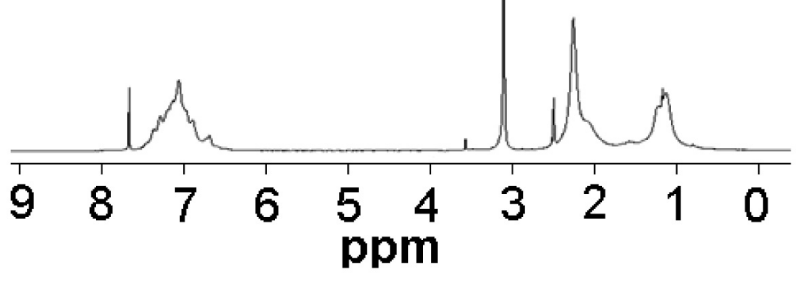

Fig. 2. ${ }^{1} \mathrm{H}-\mathrm{NMR}$ spectra of a) BMKMA monomer, b) poly(BMKMA) homopolymer.

crylic ester carbonyl carbon. The signal at $155.43 \mathrm{ppm}$ is attributed $\mathrm{C}=\mathrm{N}$ carbon. The signals at $154.84 \mathrm{ppm}$ and $149.77 \mathrm{ppm}$ correspond to ipso carbon in aromatic ring next to furan oxygen and ipso carbon in furan ring. The other signals of benzofuran group observed between 134.88 $\mathrm{ppm}$ and $111.85 \mathrm{ppm}$. The signals at $127.40 \mathrm{ppm}$ and $121.81 \mathrm{ppm}$, which are due to vinylic ipso carbon next to ester carbonyl and vinylic methylene carbon $\left(=\mathrm{CH}_{2}\right)$, respectively. The resonances for methyl carbons next to vinylic and furan groups are observed at $18.35 \mathrm{ppm}$ and 13.32 ppm, respectively.

The spectral characterization of poly(BMKMA) was also performed with FTIR and ${ }^{1} \mathrm{H}-\mathrm{NMR}$ methods. The FTIR spectrum of poly(BMKMA) was illustrated in Fig. $1 \mathrm{~b}$. The most characteristic absorption bands for polymer are as follows: The bands at 3131-3076 and 2983-2930

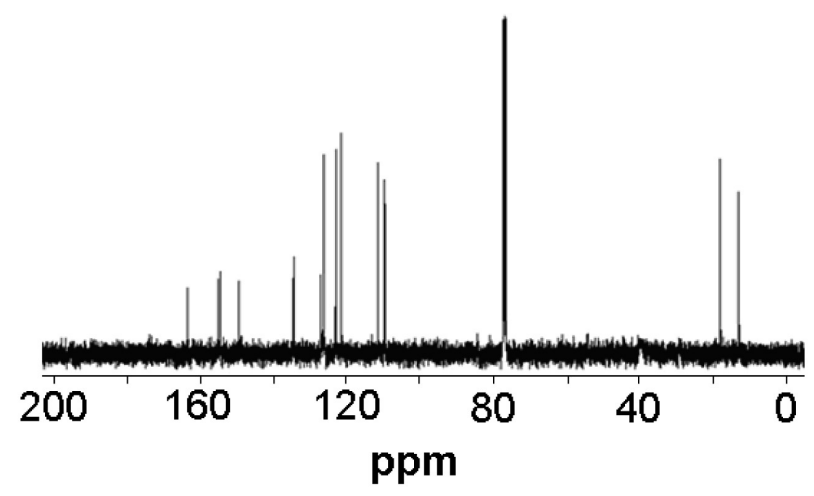

Fig. 3. ${ }^{13} \mathrm{C}-\mathrm{NMR}$ spectrum of BMKMA monomer. $\mathrm{cm}^{-1}$ are due to aromatic and aliphatic $\mathrm{C}-\mathrm{H}$ stretching vibrations, respectively. The absorption peak for ester carbonyl is observed at the vibration frequency $1758 \mathrm{~cm}^{-1}$. The band at $1611 \mathrm{~cm}^{-1}$ is attributed to $\mathrm{C}=\mathrm{N}$ stretching. In the frequency region of $\mathrm{C}=\mathrm{C}$ stretching, only the absorption band at $1602 \mathrm{~cm}^{-1}$ for aromatic $\mathrm{C}=\mathrm{C}$ stretching was observed whereas the aliphatic $\mathrm{C}=\mathrm{C}$ stretching wasn't. The disappearance of aliphatic $\mathrm{C}=\mathrm{C}$ stretching is one of the main evidences that the homopolymerization of BMKMA is accomplished by free radical polymerization method. The band at $1071 \mathrm{~cm}^{-1}$ is also attributable to symmetric C-O-C stretching vibration. On the ${ }^{1} \mathrm{H}-\mathrm{NMR}$ spectrum of the poly(BMKMA) shown in Fig. 2b, the resonances between $7.69 \mathrm{ppm}$ and $6.92 \mathrm{ppm}$ are assigned to $=\mathrm{CH}$ protons on the benzofuran ring. The backbone methylene protons are observed at the resonances between $2.51-2.16 \mathrm{ppm}$ while the methyl protons are between 1.24-1.14 ppm. The another main evidence that the homopolymerization is accomplished is disappearance of two singlet resonances at $6.13 \mathrm{ppm}$ and $5.53 \mathrm{ppm}$ assigned to vinylic protons of BMKMA monomer, and is also appearance of new broad signals at chemical shifting of 2.51-2.16 ppm and 1.24-1.14 ppm, which are due to methylene and methyl protons on the homopolymer backbone.

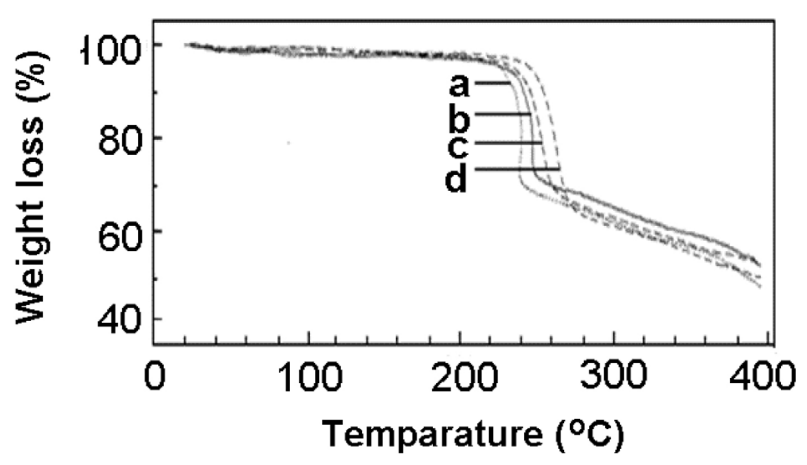

Fig. 4. TGA curves of poly(BMKMA) homopolymer at different heating rates: a) $5{ }^{\circ} \mathrm{C} / \mathrm{min}$, b) $10{ }^{\circ} \mathrm{C} / \mathrm{min}$, c) $15^{\circ} \mathrm{C} / \mathrm{min}$, d) 20 ${ }^{\circ} \mathrm{C} / \mathrm{min}$

Kinetic parameters and thermal characteristics of poly(BMKMA) samples were determined by thermogravimetric analysis (TGA) under conditions of non-isothermal heating. The dynamic experiments of degradation were performed increasing the temperature up to $400{ }^{\circ} \mathrm{C}$ at heating rates of $5,10,15$ and $20^{\circ} \mathrm{C} / \mathrm{min}$ in an inert atmosphere of argon. The weight loss curves showed that decomposition of poly(BMKMA) took place in one stage in the $30 \%$ weight loss area attributed to the formation of volatile hydrocarbons in the first decomposition temperature range up to approximately $270{ }^{\circ} \mathrm{C} .{ }^{13}$ TGA curves and peak temperatures shift to higher values with an increase in the heating rate. This alteration has been recorded in the 
case of thermal degradation of different types of polymers. ${ }^{19,29,30}$ From thermogravimetric data, the fractional decomposition $(\alpha)$ values were also calculated for each heating rate, and those values continuously increased as the temperature was increased. Fig. 4 illustrates the alteration of the weight loss curves of poly(BMKMA) samples in relation to heating rate from room temperature to 400 ${ }^{\circ} \mathrm{C}$. In this thermogram, there was a lateral shift to higher temperatures for initial decomposition temperatures for all samples as the heating rates are increased. The initial

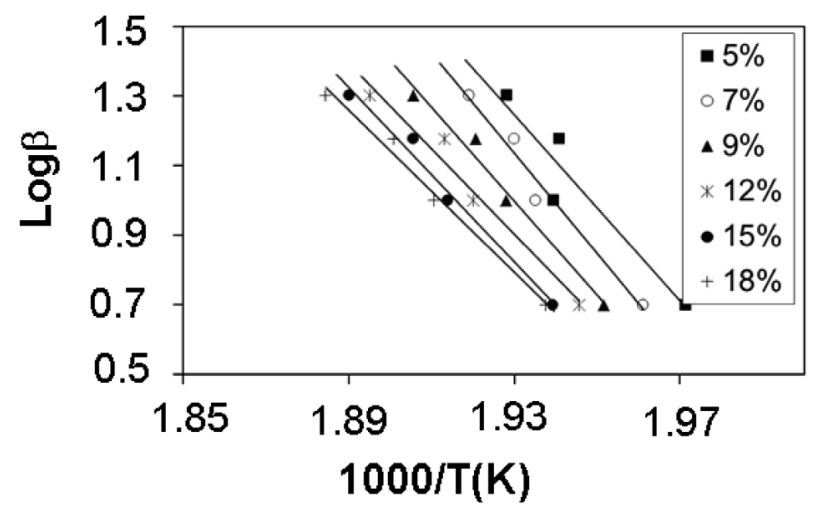

Fig. 5. Typical plots of $\log \beta$ versus (1000/T) for poly(BMKMA)

Table 1. Activation energies obtained using the Flyn-Wall-Ozawa method.

\begin{tabular}{lcc}
\hline $\boldsymbol{\alpha}(\boldsymbol{\%})$ & $\mathbf{E}(\mathbf{k J} / \mathbf{m o l})$ & $\mathbf{r}$ \\
\hline 5 & 243.4 & 0.897 \\
7 & 262.3 & 0.973 \\
9 & 245.9 & 0.980 \\
12 & 222.9 & 0.970 \\
15 & 229.0 & 0.983 \\
18 & 212.1 & 0.986 \\
Mean & 235.9 & \\
\hline
\end{tabular}

decomposition temperatures at heating rates of $5,10,15$ and $20^{\circ} \mathrm{C} / \mathrm{min}$ were determined as $203,210,213$ and 215 ${ }^{\circ} \mathrm{C}$, respectively.

In the present study, we determined the decomposition activation energies and the solid state thermodegradation mechanism of polymer for only the first decomposition range that corresponds to initial decomposition range at different heating rates. For this purpose, we used different integral and differential methods to evaluate the kinetic information of poly(BMKMA). The Flynn-WallOzawa method ${ }^{24,25}$ is one of the integral methods to determine the activation energy without knowledge of reaction order. It is used to determine the activation energy for given values of conversion using Eq. 4. Fig. 5 shows the plots of $\log \beta$ against 1000/T where the fitting straight lines are nearly parallel. This is a important information that the applicability of Flynn-Wall-Ozawa method to thermal degradation of poly(BMKMA) polymer at applied conversions may be valid. The activation energies estimated at different conversions are listed in Table 1. The mean activation energy value in Table 1 was found to be $235.9 \mathrm{~kJ} / \mathrm{mol}$.

Coats-Redfern method ${ }^{26}$ was used in order to determine the most probable thermal degradation mechanism of poly(BMKMA). If the correct $g(\alpha)$ is used, a plot of $\ln \left[g(\alpha) / T^{2}\right]$ against $1000 / T$ will give a straight line, and the values of the apparent activation energy $E$ can easily be determined from its slope. In the case of polymers, the degradation process usually continues as either a sigmoidal (nucleation and growth) or a deceleration (phase boundary reaction or diffusion) function. The apparent activation energies and correlations are tabulated in Tables ( 2 to 5 ) for heating rates of $5,10,15$ and $20^{\circ} \mathrm{C} / \mathrm{min}$, respectively. In this study, we have compared the apparent activation energies obtained with the Coats-Redfern method to the method of Flynn-Wall-Ozawa to determine the thermal degradation mechanism of poly(BMKMA) polymer. The reason of chosen the Flynn-Wall-Ozawa method for

Table 2. Activation energies obtained for several solid state processes at a heating rate of $5{ }^{\circ} \mathrm{C} / \mathrm{min}$

\begin{tabular}{|c|c|c|c|c|c|c|}
\hline \multirow{2}{*}{ Mechanism } & \multicolumn{2}{|c|}{ Coats-Redfern Method } & \multicolumn{2}{|c|}{ Madhusudanan Method } & \multicolumn{2}{|c|}{ Van Krevelen Method } \\
\hline & $E(\mathrm{~kJ} / \mathrm{mol})$ & $r$ & $E(\mathbf{k J} / \mathbf{m o l})$ & $E(\mathbf{k J} / \mathbf{m o l})$ & $E(\mathbf{k J} / \mathbf{m o l})$ & $r$ \\
\hline $\mathrm{A}_{2}$ & 140.9 & 0.986 & 141.1 & 0.986 & 146.9 & 0.988 \\
\hline $\mathrm{A}_{3}^{2}$ & 91.1 & 0.985 & 91.3 & 0.985 & 96.5 & 0.988 \\
\hline $\mathrm{A}_{4}$ & 66.2 & 0.984 & 66.5 & 0.984 & 71.3 & 0.987 \\
\hline $\mathrm{R}_{1}^{4}$ & 277.5 & 0.989 & 277.7 & 0.989 & 285.4 & 0.990 \\
\hline $\mathrm{R}_{2}$ & 283.8 & 0.987 & 283.9 & 0.987 & 291.7 & 0.989 \\
\hline $\mathrm{R}_{3}$ & 285.9 & 0.987 & 286.1 & 0.987 & 293.8 & 0.988 \\
\hline $\mathrm{D}_{1}$ & 563.7 & 0.989 & 563.5 & 0.989 & 574.9 & 0.990 \\
\hline $\mathrm{D}_{2}$ & 571.9 & 0.988 & 571.8 & 0.988 & 583.1 & 0.989 \\
\hline $\mathrm{D}_{3}$ & 580.4 & 0.987 & 580.2 & 0.987 & 591.7 & 0.988 \\
\hline $\mathrm{D}_{4}$ & 574.8 & 0.988 & 574.5 & 0.988 & 586.1 & 0.989 \\
\hline $\mathrm{F}_{1}$ & 290.2 & 0.986 & 290.3 & 0.986 & 298.2 & 0.987 \\
\hline $\mathrm{F}_{2}$ & 17.2 & 0.751 & 17.6 & 0.758 & 21.8 & 0.872 \\
\hline $\mathrm{F}_{3}$ & 43.0 & 0.824 & 43.3 & 0.826 & 47.8 & 0.872 \\
\hline
\end{tabular}


comparison is due to the independent from a particular mechanism. Analyzing of Table 4, it should be noted for all the samples studied that the activation energy value of polymer corresponding to a mechanism of $R_{1}$ was 236.9 $\mathrm{kJ} / \mathrm{mol}$ at heating rate $15{ }^{\circ} \mathrm{C} / \mathrm{min}$. This value is very close $235.9 \mathrm{~kJ} / \mathrm{mol}$ by Flynn-Wall-Ozawa method. These results strongly suggest that the thermal degradation mechanism of poly(BMKMA) is a deceleration type, phase boundary controlled reaction $\left(R_{1}\right)$.

As well as the Coats-Redfern method, the most probable mechanism may also be determined providing that Eq. 3 is solved in different ways. Thus, the accuracy of calculation may be increased. Two methods, which are Madhusudanan method ${ }^{27}$ and Van Krevelen ${ }^{28}$ method, were used to verify the solid state thermodegradation mechanism of polymer. The decomposition activation energies and correlations for thermal degradation of poly(BMKMA) polymer at different heating rates are also summarized in Tables ( 2 to 5). When the activation energies and correlation coefficients of linear regression were calcula- ted according to the Madhusudanan method (Eq. 6) using integral functions, the activation energy value was obtained at the heating rate of $15{ }^{\circ} \mathrm{C} / \mathrm{min}$ corresponding to a deceleration $R_{1}$ mechanism in Table 4, which was found to be $237.0 \mathrm{~kJ} / \mathrm{mol}$ with the best correlation (0.994). These values are in good agreement with the value obtained with the Flynn-Wall-Ozawa method.

To corroborate that poly(BMKMA) polymer follows phase boundary controlled reaction of deceleration type $\left(\mathrm{R}_{1}\right)$ of thermal decomposition mechanism, we have also used the Van Krevelen method. The activation energies of every $g(\alpha)$ function were calculated from the slope of lines of $\log g(\alpha)$ versus $\log$ T plots using $E q$. 7. The activation energies and correlations at the conversion range are given in Tables ( 2 to 5 ) for different heating rates. The best agreement was determined for $\mathrm{R}_{\mathrm{n}}$ reaction mechanisms in all heating rates. In particular, the activation energy calculated for $\mathrm{R}_{1}$ process given in Table 4 at a heating rate of 15 ${ }^{\circ} \mathrm{C} / \mathrm{min}$ is $244.6 \mathrm{~kJ} / \mathrm{mol}$, which is in good agreement with the Flynn-Wall-Ozawa method that of $235.9 \mathrm{~kJ} / \mathrm{mol}$.

Table 3. Activation energies obtained for several solid state processes at a heating rate of $10{ }^{\circ} \mathrm{C} / \mathrm{min}$

\begin{tabular}{cccccr}
\hline \multirow{2}{*}{ Mechanism } & \multicolumn{2}{c}{ Coats-Redfern Method } & \multicolumn{2}{c}{ Madhusudanan Method } & \multicolumn{2}{c}{ Van Krevelen Method } \\
& $\boldsymbol{E}(\mathbf{k J} / \mathbf{m o l})$ & $\boldsymbol{r}$ & $\boldsymbol{E}(\mathbf{k J} / \mathbf{m o l})$ & $\boldsymbol{E}(\mathbf{k J} / \mathbf{m o l})$ & $\boldsymbol{E}(\mathbf{k J} / \mathbf{m o l})$ \\
\hline $\mathrm{A}_{2}$ & 147.6 & 0.977 & 147.8 & 0.978 & 153.8 \\
$\mathrm{~A}_{3}$ & 95.5 & 0.976 & 95.8 & 0.976 & 0.981 \\
$\mathrm{~A}_{4}$ & 69.5 & 0.975 & 69.8 & 0.975 & 0.981 \\
$\mathrm{R}_{1}$ & 290.5 & 0.981 & 290.6 & 0.981 & 0.9 \\
$\mathrm{R}_{2}$ & 297.1 & 0.980 & 297.2 & 0.980 & 298.5 \\
$\mathrm{R}_{3}$ & 299.3 & 0.979 & 299.4 & 0.979 & 305.2 \\
$\mathrm{D}_{1}$ & 589.6 & 0.981 & 589.5 & 0.981 & 307.4 \\
$\mathrm{D}_{2}$ & 598.3 & 0.980 & 598.1 & 0.980 & 601.3 \\
$\mathrm{D}_{3}$ & 607.2 & 0.980 & 607.1 & 0.980 & 610.0 \\
$\mathrm{D}_{4}$ & 601.3 & 0.980 & 601.1 & 0.980 & 0.981 \\
$\mathrm{~F}_{1}$ & 303.8 & 0.979 & 303.8 & 0.979 & 0.982 \\
$\mathrm{~F}_{2}$ & 18.4 & 0.763 & 18.8 & 0.770 & 613.1 \\
$\mathrm{~F}_{3}$ & 45.5 & 0.830 & 45.8 & 0.832 & 0.981 \\
\hline
\end{tabular}

Table 4. Activation energies obtained for several solid state processes at a heating rate of $15{ }^{\circ} \mathrm{C} / \mathrm{min}$

\begin{tabular}{|c|c|c|c|c|c|c|}
\hline \multirow{2}{*}{ Mechanism } & \multicolumn{2}{|c|}{ Coats-Redfern Method } & \multicolumn{2}{|c|}{ Madhusudanan Method } & \multicolumn{2}{|c|}{ Van Krevelen Method } \\
\hline & $E(\mathrm{~kJ} / \mathbf{m o l})$ & $r$ & $E(\mathrm{~kJ} / \mathbf{m o l})$ & $E(\mathbf{k J} / \mathbf{m o l})$ & $E(\mathbf{k J} / \mathbf{m o l})$ & $r$ \\
\hline $\mathrm{A}_{2}$ & 119.6 & 0.992 & 119.8 & 0.992 & 125.7 & 0.993 \\
\hline $\mathrm{A}_{3}$ & 76.9 & 0.991 & 77.1 & 0.991 & 82.3 & 0.993 \\
\hline $\mathrm{A}_{4}^{3}$ & 55.5 & 0.991 & 55.8 & 0.991 & 60.7 & 0.993 \\
\hline $\mathrm{R}_{1}^{4}$ & 236.9 & 0.994 & 237.0 & 0.994 & 244.6 & 0.995 \\
\hline $\mathrm{R}_{2}$ & 242.3 & 0.993 & 242.4 & 0.993 & 250.1 & 0.994 \\
\hline $\mathrm{R}_{3}$ & 244.1 & 0.993 & 244.2 & 0.993 & 251.9 & 0.994 \\
\hline $\mathrm{D}_{1}$ & 482.3 & 0.994 & 482.3 & 0.994 & 493.4 & 0.995 \\
\hline $\mathrm{D}_{2}$ & 489.4 & 0.994 & 489.4 & 0.994 & 500.8 & 0.995 \\
\hline $\mathrm{D}_{3}$ & 496.8 & 0.993 & 496.7 & 0.993 & 508.3 & 0.994 \\
\hline $\mathrm{D}_{4}$ & 491.9 & 0.993 & 491.8 & 0.993 & 503.0 & 0.994 \\
\hline $\mathrm{F}_{1}$ & 247.8 & 0.992 & 247.9 & 0.992 & 255.7 & 0.993 \\
\hline $\mathrm{F}_{2}$ & 13.6 & 0.750 & 13.9 & 0.759 & 18.2 & 0.890 \\
\hline $\mathrm{F}_{3}$ & 35.9 & 0.838 & 36.2 & 0.840 & 40.8 & 0.890 \\
\hline
\end{tabular}


Table 5. Activation energies obtained for several solid state processes at a heating rate of $20{ }^{\circ} \mathrm{C} / \mathrm{min}$

\begin{tabular}{|c|c|c|c|c|c|c|}
\hline \multirow{2}{*}{ Mechanism } & \multicolumn{2}{|c|}{ Coats-Redfern Method } & \multicolumn{2}{|c|}{ Madhusudanan Method } & \multicolumn{2}{|c|}{ Van Krevelen Method } \\
\hline & $E(\mathrm{~kJ} / \mathrm{mol})$ & $r$ & $E(\mathrm{~kJ} / \mathrm{mol})$ & $E(\mathrm{~kJ} / \mathbf{m o l})$ & $E(\mathbf{k J} / \mathbf{m o l})$ & $r$ \\
\hline $\mathrm{A}_{2}$ & 89.9 & 0.959 & 90.1 & 0.959 & 97.7 & 0.967 \\
\hline $\mathrm{A}_{3}^{2}$ & 57.0 & 0.955 & 57.3 & 0.956 & 63.7 & 0.967 \\
\hline $\mathrm{A}_{4}$ & 40.6 & 0.951 & 40.9 & 0.951 & 46.6 & 0.967 \\
\hline $\mathrm{R}_{1}^{4}$ & 180.2 & 0.966 & 180.3 & 0.966 & 191.5 & 0.971 \\
\hline $\mathrm{R}_{2}$ & 184.2 & 0.964 & 182.9 & 0.964 & 195.7 & 0.969 \\
\hline $\mathrm{R}_{3}$ & 185.8 & 0.964 & 185.8 & 0.964 & 197.1 & 0.969 \\
\hline $\mathrm{D}_{1}$ & 369.0 & 0.968 & 369.0 & 0.968 & 387.4 & 0.971 \\
\hline $\mathrm{D}_{2}$ & 374.4 & 0.966 & 374.3 & 0.967 & 393.0 & 0.970 \\
\hline $\mathrm{D}_{3}$ & 379.9 & 0.965 & 379.9 & 0.965 & 398.7 & 0.969 \\
\hline $\mathrm{D}_{4}$ & 376.2 & 0.966 & 376.2 & 0.966 & 394.9 & 0.969 \\
\hline $\mathrm{F}_{1}^{4}$ & 188.3 & 0.962 & 188.5 & 0.963 & 200.0 & 0.827 \\
\hline $\mathrm{F}_{2}$ & 8.0 & 0.522 & 8.4 & 0.542 & 12.9 & 0.827 \\
\hline $\mathrm{F}_{3}$ & 24.7 & 0.719 & 25.0 & 0.725 & 30.2 & 0.827 \\
\hline
\end{tabular}

\section{Conclusions}

Thermal degradation mechanism and activation energies for initial decomposition process under non-isothermal conditions of a novel benzofuran ketoxime polymer, poly(benzofuran-2-yl-methylketoxime-O-methacrylate), were determined by integral approximation methods from the thermogravimetric study. The activation energy of the solid-state process was determined using FlynnWall-Ozawa method, which resulted to be $235.9 \mathrm{~kJ} / \mathrm{mol}$. The study of kinetic equations showed that the reaction mechanism of the decomposition process in the conversion range studied progressed with $\mathrm{R}_{1}$ mechanism, phase boundary controlled (one-dimensional movement) of deceleration type of solid state mechanism. The best conformity in all integral methods and heating rates to that of the Flynn-Wall-Ozawa model was obtained in the case of the Coats-Redfern method $(E=236.9 \mathrm{~kJ} / \mathrm{mol})$ at a heating rate of $15{ }^{\circ} \mathrm{C} / \mathrm{min}$.

\section{Acknowledgment}

We wish to thank the Adiyaman University Research Fund for financial support this study (FEFYL 2010/0002).

\section{References}

1. E. B. Anderson, T. E. Long, Polymer 2010, 51, 2447-2454. http://dx.doi.org/10.1016/j.polymer.2010.02.006

2. Y. Suzuki, R. J. Ono, M. Ueda, C. W. Bielawski, Eur. Polym. J. 2013, 49, 4276-4280.

http://dx.doi.org/10.1016/j.eurpolymj.2013.09.023

3. Takakazu, Y. B. C. S. J. 2010, 83, 431-455.

4. J. A Johnson, Y. Y. Lu, A. O. Burts, Y. Xia, A. C. Durrell, D.
A. Tirrell, R. H. Grubbs, Macromolecules 2010, 43, 1032610335. http://dx.doi.org/10.1021/ma1021506

5. A. B. Powell, C. W. Bielawski, A.H. Cowley, J. Am. Chem. Soc. 2010, 132, 10184-10194.

http://dx.doi.org/10.1021/ja104051x

6. J. L. T. Mathieu, E. Brulé, P. Haquettea, C. M. Thomas, Polym. Chem. 2012, 3, 836-851.

http://dx.doi.org/10.1039/C2PY00452F

7. B. C. Norris, C. W. Bielawski, Macromolecules 2010, 43, 3591-3593. http://dx.doi.org/10.1021/ma100524g

8. M. Foroutan, A. T. Nasrabadi, J. Phys. Chem. B 2010, 114, 5320-5326. http://dx.doi.org/10.1021/jp100960u

9. M. D. Damaceanu, R. D. Rusu, M. Bruma, Polym. Adv. Technol. 2011, 22, 420-429. http://dx.doi.org/10.1002/pat.1519

10. W. Yuan, S. Ma, S. Org. Lett. 2014, 16, 193-195. http://dx.doi.org/10.1021/ol4032254

11. Y. Y. Li, A. M. Ren, J. K. Feng, L. Yang, C. C. Sun, Opt. Mater. 2007, 29, 1571-1578. http://dx.doi.org/10.1016/j.optmat.2006.05.012

12. R. Rani, J. K. Makrandi, Indian J. Chem. B. 2009, 48, 1614 1617.

13. M. Koca, A. Kurt, C. Kirilmis, Y. Aydogdu, Polymer. Eng. Sci. 2012, 52, 323-330. http://dx.doi.org/10.1002/pen.22085

14. M. Yonezumi, S. Kanaoka, S. Aoshima, J. Polym. Sci. Pol. Chem. 2008, 46, 4495-4504. http://dx.doi.org/10.1002/pola.22785

15. J. K. Xu, G. M. Nie, S. S. Zhang, X. J. Han, S. Z. Pu, L. Shen, Q. Xiao, Eur. Polym. J. 2005, 41, 1654-1651. http://dx.doi.org/10.1016/j.eurpolymj.2005.01.014

16. A. Banihashemi, F. Atabaki, Eur. Polym. J. 2002, 38, 21192124. http://dx.doi.org/10.1016/S0014-3057(02)00081-2

17. M. Pokladko, J. Sanetra, E. Gondek, D. Bogdal, J. Niziol, I. V. Kityk, Mol. Cryst. Liq. Cryst. 2008, 484, 701-710. http://dx.doi.org/10.1080/15421400801904732

18. I. Erol, O. Sen, C. Cifci, Z. Gurler, J. Macromol. Sci. A. 2010, 47, 1032-1041. http://dx.doi.org/10.1080/10601325.2010.508015 
19. L. Li, C. Guan, A. Zhang, D. Chen, Z. Qing, Polym. Degrad. Stabil. 2004, 84, 369-373. http://dx.doi.org/10.1016/j.polymdegradstab.2003.11.007

20. J. M. Cervantes-Uc, J. V. Cauich-Rodriguez, W. A. HerreraKao, H. Vazquez-Torres, A. Marcos-Fernandez, Polym. Degrad. Stabil. 2008, 93, 1891-1900. http://dx.doi.org/10.1016/j.polymdegradstab.2008.07.003

21. E. Kaya, A. Kurt, M. Er, Journal of Nanoscience and Nanotechnology (JNN) 2012, 12, 8502-8512. http://dx.doi.org/10.1166/jnn.2012.6670

22. F. M. Uhl, G. F. Levchik, S. V. Levchik, C. Dick, J. J. Liggat, C. E. Snape, C. A. Wilkie, Polym. Degrad. Stabil. 2001, 71, 317-325. http://dx.doi.org/10.1016/S0141-3910(00)00181-6

23. Z. D. Zivkovic, J. Sestak, J. Therm. Anal. Calorim. 1998, 53, 263-267. http://dx.doi.org/10.1023/A:1010108813595
24. J. H. Flynn, L. A. Wall, J. Polymer. Sci. B Polymer. Lett. 2003, 5, 191-196.

http://dx.doi.org/10.1002/pol.1967.110050211

25. T. Ozawa J. Thermal Anal. 1986, 31, 547-551. http://dx.doi.org/10.1007/BF01914230

26. A. W. Coats, J. P. Redfern, Nature 1964, 201, 68-69. http://dx.doi.org/10.1038/201068a0

27. P. M. Madhusudanan, K. Krishnan, K. N.Ninan, Thermochim. Acta. 1993, 221, 13-21. http://dx.doi.org/10.1016/0040-6031(93)80519-G

28. D. W. Van Krevelen, C. Van Herrden, F. J. Hutjens, Fuel 1951, 30, 253-258.

29. A. Kurt, J. Appl. Polym. Sci. 2009, 114, 624-629. http://dx.doi.org/10.1002/app.30576

30. X. L. Meng, Y. D. Huang, H. Yu, Z. S. Lv, Polym. Degrad. Stabil. 2007, 92, 962-967.

http://dx.doi.org/10.1016/j.polymdegradstab.2007.03.005

\section{Povzetek}

S prostoradikalsko polimerizacijo smo sintetizirali poli(benzofuran-2-il-metilketoksime-O-metakrilat) [poly(BMKMA]. Mehanizem procesa razpada tega polimera smo proučevali s termogravimetrično analizo (TGA). Z metodo FlynnWall-Ozawa smo v trdnem določili aktivacijsko energijo $235.9 \mathrm{~kJ} / \mathrm{mol}$. Vrednosti aktivacijskih energij smo določili tudi s kinetičnimi modeli Coats-Redferna, Madhusudanana in van Krevelena ter s primerjavo vrednosti sklepali, da je dejanski mehanizem razpada reakcija, kontrolirana s procesi na fazni meji. 